\title{
Comparison of oral-health-related quality of life in patients in the short- and long-term period following lower-facial injury and fractures - preliminary report
}

\section{Porównanie jakości życia związanej ze stanem jamy ustnej w obserwacji krótko- i długoterminowej u pacjentów po urazach i złamaniach dolnej części twarzy - obserwacje wstępne}

\author{
Bogumił Lewandowski ${ }^{1,2, A, E, F}$, Ewa Szeliga ${ }^{3, A, B}$, Ewelina Czenczek-Lewandowska ${ }^{3, D}$, Dorota Ozga ${ }^{4, E}$, Aldona Kontek ${ }^{3, B, D}$, \\ Małgorzata Migut ${ }^{1,2, C}$, Grzegorz Magoń ${ }^{3, C}$, Justyna Kosydar-Bochenek ${ }^{2, C}$, Adrian Kużdżał, ${ }^{3, C}$ \\ 1 Department of Maxillofacial Surgery, Frederic Chopin Clinical Voivodeship Hospital in Rzeszów, Poland \\ ${ }^{2}$ Department of Emergency Medicine, Faculty of Medicine, University of Rzeszów, Poland \\ ${ }^{3}$ Institute of Physiotherapy, Faculty of Medicine, University of Rzeszów, Poland \\ ${ }^{4}$ Department of Didactics in Intensive Medical Care and Emergency Medicine, Faculty of Medicine, University of Rzeszów, Poland \\ A - research concept and design; $B$ - collection and/or assembly of data; $C$ - data analysis and interpretation; \\ $D$ - writing the article; $E$ - critical revision of the article; $F$ - final approval of the article
}

Address for correspondence

Dorota Ozga

E-mail: gdozga@poczta.fm

Funding sources

None declared

Conflict of interest

None declared

Received on November 30, 2017 Reviewed on December 30, 2017 Accepted on February 12, 2018

D0I

$10.17219 / \mathrm{dmp} / 85255$

Copyright

○ 2018 by Wroclaw Medical University

and Polish Dental Society

This is an article distributed under the terms of the

Creative Commons Attribution Non-Commercial License

(http://creativecommons.org/licenses/by-nc-nd/4.0/)

\begin{abstract}
Background. Post-traumatic craniofacial injuries associated with bone fractures lead to serious morphological, functional and aesthetic complications which may negatively affect the physical and mental condition of the patient throughout the recovery period.

Objectives. The aim of this study was the evaluation of complaints and well-being in patients during the short- and long-term period following injury to the lower face, as well as an assessment of the effects of age and sex in the examined parameters.

Material and methods. The research group included 42 patients with injury to the lower face. The patients'sell-being and the most common functional problems following treatment were assessed using Oral Health Impact Profile-14 (OHIP-14). Statistical analyses were performed using the Mann-Whitney U test and Spearman's rank correlation coefficient, with significance level assumed at $p<0.05$.

Results. A period of 8 months following injury of the lower face was sufficient for the patients to achieve significant improvement in the quality of life. Improvement in well-being, according to OHIP-14, by approx. 11.9 points \pm 11.7 points, was highly significant $(p<0.001)$. The most frequent complaints included pain in the maxillofacial area, difficulties with consumption of food and dissatisfaction due to the necessary change of diet. The factors of age $(p=0.2839)$ and sex $(p=0.6047)$ did not significantly affect improvement in well-being.

Conclusions. During both the short- and long-term period following injury of the lower face, the most frequent complaints included pain in the maxillofacial region, problems with eating food and dissatisfaction due to change in diet. The study has shown that during the period of 8 months after the injury, there was a significant improvement in the quality of life assessed with OHIP-14. Age and gender do not significantly affect the quality of life after injury to the lower face.
\end{abstract}

Key words: quality of life, oral health, injuries of lower face

Słowa kluczowe: jakość życia, stan zdrowia jamy ustnej, urazy dolnej części twarzy 


\section{Introduction}

Post-traumatic craniofacial injuries in adults and recovery thereafter are important clinical issues in contemporary medicine. According to statistics, in highly-developed countries injuries of this type are most commonly incurred during road traffic accidents. ${ }^{1,2}$ It has been estimated that up to $60 \%$ of all traffic accidents lead to craniofacial injuries, and $62 \%$ of these involve motorcyclists. ${ }^{3}$ Other frequent causes include falls, assaults, and sporting injuries. ${ }^{4,5}$ Based on epidemiological data, it has been suggested such injuries are most frequently incurred by males in their twenties and thirties. ${ }^{6,7}$

Regardless of their intensity and origin, craniofacial injuries rank among the most dangerous, and frequently life-threatening traumas, and often require immediate surgery. This is linked with a significant risk of damage to the vital organs of the body located within the head and neck region, i.e. the central nervous system (CNS), eyes, ears, trachea, larynx and esophagus. ${ }^{8}$ Severe craniofacial trauma, accompanied by bone fractures, results in serious morphological, functional and aesthetic complications, directly affecting the quality of the patient's performance in daily life and recovery. ${ }^{9}$

In the literature, we can find numerous reports related to the effects of conservative and surgical treatment applied to patients with oral and maxillofacial injuries, yet there are only a few studies discussing the problems encountered by patients in the post-operative period, including those related to both the physical condition of the stomatognathic system and mental well-being. ${ }^{10}$ Additionally, it is important how patients understand the possible consequences, and relationship between maxillofacial impairments and daily functioning. ${ }^{11}$

This study was designed to evaluate the most frequent symptoms and complaints affecting the well-being of patients in the short- and long-term period following injury to the lower face. The aim was also to assess the effects of age and sex in the parameters examined.

\section{Material and methods}

Selected from among 66 subjects, the study group comprised 42 patients, including 13 females (31\%) and 29 males (69\%) ranging from 17 to 59 years of age (mean 34.5 years \pm 13.2 years). The patients had surgical treatment of mandibular fractures at the Maxillofacial Surgery Clinic of the Fryderic Chopin Clinical Voivodeship Hospital in Rzeszów, Poland. The most common area of fracture was the body, condyle and angle of the mandible. Inclusion criteria were as follows: 1) an informed consent to participate in the research, 2) injury of the lower face as a result of trauma, 3) surgical treatment of the lower face, i.e. the mandible. The study was approved by the ethics committee of the Medical Department of the University of Rzeszów.
The assessments were carried out at 2 days and then 8 months after the injury to the lower face, with the use of the Oral Health Impact Profile (OHIP-14) questionnaire and additionally included questions specially designed for this purpose and addressing the characteristics of the study group and the patients' complaints preceding the surgery. The OHIP-14 scale developed by Slade and Spencer is used to assess the effects of impairments related to the oral cavity and their impact on the patient's quality of life. The questions focus on 7 domains, defined by the authors as: functional limitation, physical pain, psychological discomfort, physical, psychological and social disability, and handicap. The questionnaire contains 14 questions ( 2 in each of the 7 categories), addressing e.g. co-existing complaints, i.e. orofacial pain, discomfort during eating and problems with falling asleep. Responses are assessed on a 4-point Likert scale, where 0 means "never", 1 - "hardly ever" 2 - "occasionally", 3 - "fairly often" and 4 - "very often". Patients' score may be in the range from 0 to 56 points, and the highest number of points reflects the poorest oral health and well-being. ${ }^{12-13}$ The results acquired were subjected to statistical analyses, with significance level assumed at $\mathrm{p}<0.05$ (marked with *). The analyses performed using the Mann-Whitney U test and Spearman's rank correlation coefficient were verified with the Shapiro-Wilk test and Levene's test.

\section{Results}

\section{Complaints related to the maxillofacial region in the short post-traumatic period}

During the short period after the injury, i.e. 2 days after trauma, the patients' complaints mainly related to physical pain, followed by physical disability and psychological discomfort. Painful aching in the mouth, experienced very often -4 , or often -3 , was reported by a total of $50 \%$ of the subjects, while discomfort during eating by as many as $66.7 \%$, which may have been linked to the lack of satisfaction due to the necessary change in diet, expressed by $54.8 \%$ of the subjects. A significant part of the group manifested poor psychological well-being, which was particularly linked with the awareness of the existing problems in the maxillofacial region, expressed by $54.8 \%$ of the patients. The data is shown in Table 1.

\section{Complaints related to the maxillofacial region in the long post-traumatic period}

The findings of the assessment involving the same patients, and carried out 8 months after the trauma, are presented in Table 2 . The most commonly persisting complaints, on the scale marked as experienced very often -4 or often -3 , related to the same domains of the 
Table 1. Complaints in the facial area of the cranium according to OHIP-14 - 2 days after trauma

\begin{tabular}{|c|c|c|c|c|c|c|c|}
\hline $\begin{array}{l}\text { Subscales } \\
\text { (domains) }\end{array}$ & OHIP-14 (Oral Health Impact Profile) & \begin{tabular}{c|c}
$n$ \\
$(\%)$
\end{tabular} & Very often & Fairly often & Occasionally & Hardly ever & Never \\
\hline \multirow{4}{*}{$\begin{array}{l}\text { Functional } \\
\text { limitation }\end{array}$} & \multirow{2}{*}{$\begin{array}{l}\text { 1. Have you had trouble pronouncing any words because } \\
\text { of problems with your teeth, mouth or dentures? }\end{array}$} & $n$ & 4 & 9 & 9 & 7 & 13 \\
\hline & & $\%$ & 9.50 & 21.40 & 21.40 & 16.70 & 31.00 \\
\hline & \multirow{2}{*}{$\begin{array}{l}\text { 2. Have you felt that your sense of taste has worsened because } \\
\text { of problems with your teeth, mouth or dentures? }\end{array}$} & $n$ & 5 & 3 & 7 & 9 & 18 \\
\hline & & $\%$ & 11.90 & 7.10 & 16.70 & 21.40 & 42.90 \\
\hline \multirow{4}{*}{$\begin{array}{l}\text { Physical } \\
\text { pain }\end{array}$} & \multirow{2}{*}{ 3. Have you had painful aching in your mouth? } & $n$ & 7 & 14 & 9 & 6 & 6 \\
\hline & & $\%$ & 16.70 & 33.30 & 21.40 & 14.30 & 14.30 \\
\hline & \multirow{2}{*}{$\begin{array}{l}\text { 4. Have you found it uncomfortable to eat any foods because } \\
\text { of problems with your teeth, mouth or dentures? }\end{array}$} & $n$ & 16 & 12 & 2 & 7 & 5 \\
\hline & & $\%$ & 38.10 & 28.60 & 4.80 & 16.70 & 11.90 \\
\hline \multirow{4}{*}{$\begin{array}{l}\text { Psychological } \\
\text { discomfort }\end{array}$} & \multirow{2}{*}{$\begin{array}{l}\text { 5. Have you been aware of problems with your teeth, } \\
\text { mouth or dentures? }\end{array}$} & $n$ & 12 & 11 & 5 & 2 & 12 \\
\hline & & $\%$ & 28.60 & 26.20 & 11.90 & 4.80 & 28.60 \\
\hline & \multirow{2}{*}{$\begin{array}{l}\text { 6. Have you felt tense because of problems with your teeth, } \\
\text { mouth or dentures? }\end{array}$} & $n$ & 6 & 9 & 13 & 4 & 10 \\
\hline & & $\%$ & 14.30 & 21.40 & 31.00 & 9.50 & 23.80 \\
\hline \multirow{4}{*}{$\begin{array}{l}\text { Physical } \\
\text { disability }\end{array}$} & \multirow{2}{*}{$\begin{array}{l}\text { 7. Has your diet been unsatisfactory because of problems } \\
\text { with your teeth, mouth or dentures? }\end{array}$} & $\mathrm{n}$ & 11 & 12 & 4 & 8 & 7 \\
\hline & & $\%$ & 26.20 & 28.60 & 9.50 & 19.00 & 16.70 \\
\hline & \multirow{2}{*}{$\begin{array}{l}\text { 8. Have you had to interrupt meals because of problems } \\
\text { with your teeth, mouth or dentures? }\end{array}$} & $n$ & 6 & 12 & 6 & 7 & 11 \\
\hline & & $\%$ & 14.30 & 28.60 & 14.30 & 16.70 & 26.20 \\
\hline \multirow{4}{*}{$\begin{array}{l}\text { Psychological } \\
\text { disability }\end{array}$} & \multirow{2}{*}{$\begin{array}{l}\text { 9. Have you found it difficult to relax because of problems } \\
\text { with your teeth, mouth or dentures? }\end{array}$} & $n$ & 5 & 9 & 10 & 6 & 12 \\
\hline & & $\%$ & 11.90 & 21.40 & 23.80 & 14.30 & 28.60 \\
\hline & \multirow{2}{*}{$\begin{array}{l}\text { 10. Have you been a bit embarrassed because of problems } \\
\text { with your teeth, mouth or dentures? }\end{array}$} & $n$ & 7 & 10 & 8 & 8 & 9 \\
\hline & & $\%$ & 16.70 & 23.80 & 19.00 & 19.00 & 21.40 \\
\hline \multirow{4}{*}{$\begin{array}{l}\text { Social } \\
\text { disability }\end{array}$} & \multirow{2}{*}{$\begin{array}{l}\text { 11. Have you been a bit irritable with other people because } \\
\text { of problems with your teeth, mouth or dentures? }\end{array}$} & $n$ & 4 & 6 & 4 & 9 & 19 \\
\hline & & $\%$ & 9.50 & 14.30 & 9.50 & 21.40 & 45.20 \\
\hline & \multirow{2}{*}{$\begin{array}{l}\text { 12. Have you had difficulty doing your usual jobs because } \\
\text { of problems with your teeth, mouth or dentures? }\end{array}$} & $n$ & 5 & 7 & 5 & 5 & 20 \\
\hline & & $\%$ & 11.90 & 16.70 & 11.90 & 11.90 & 47.60 \\
\hline \multirow{4}{*}{ Handicap } & \multirow{2}{*}{$\begin{array}{l}\text { 13. Have you felt that life in general was less satisfying because } \\
\text { of problems with your teeth, mouth or dentures? }\end{array}$} & $n$ & 8 & 3 & 12 & 8 & 11 \\
\hline & & $\%$ & 19.00 & 7.10 & 28.60 & 19.00 & 26.20 \\
\hline & \multirow{2}{*}{$\begin{array}{l}\text { 14. Have you been totally unable to function because } \\
\text { of problems with your teeth, mouth or dentures? }\end{array}$} & $n$ & 4 & 1 & 9 & 8 & 20 \\
\hline & & $\%$ & 9.50 & 2.40 & 21.40 & 19.00 & 47.60 \\
\hline
\end{tabular}

quality of life which were most problematic during the short term period after the trauma; first of all, psychological discomfort linked with an awareness of the persisting problems, reported by $23.8 \%$ of the subjects, then physical pain, in particular in the oral cavity, reported by $16.6 \%$, and dissatisfaction with the necessary change in diet by $14.3 \%$.

\section{Comparison of OHIP's 14 parameters on the second day after trauma and 8 months later}

The assessment conducted on the $2^{\text {nd }}$ day after trauma showed the following results: out of the maximum possible score of 56 points on the OHIP-14 scale, the subjects' mean score was 25.1 points \pm 15.5 points. The lowest recorded value equaled 0 points (the best frame of mind) and the largest was 56 points (the poorest frame of mind). The median value in the first assessment was 24.5 points, which means that half of the subjects assessing their well-being on the OHIP-14 scale received a maximum of 24.5 points and the other half of the subjects scored at least 24.5 points.

The assessment performed with the OHIP-14 scale 8 months after the trauma showed the subjects on average scored 13.2 points \pm 13.8 points. The median value in this case was only 9.5 points. The minimum and maximum values in the $2^{\text {nd }}$ measurement were the same as in the $1^{\text {st }}$ one, i.e. 0 and 56 points, respectively.

The identified improvement in well-being, according to OHIP-14, by approx. 11.9 points \pm 11.7 points (approx. $47.4 \%$ in comparison to the initial value) was highly significant, at the level of $\mathrm{p}<0.001 \%$ ( $\mathrm{p}=0.0000$; $\mathrm{Z}=4.87)$ in the Wilcoxon signed-rank test. The data is shown in Table 3.

A change in well-being between the measurement 2 days after the trauma and the measurement 8 months after the trauma was found in the case of 39 respondents (92.4\%). Only 3 subjects (7.1\%) were found with no change in the level of well-being. 
Table 2. Complaints in the facial area of the cranium according to OHIP-14 - 8 months after trauma

\begin{tabular}{|c|c|c|c|c|c|c|c|}
\hline $\begin{array}{l}\text { Subscales } \\
\text { (domains) }\end{array}$ & OHIP-14 (Oral Health Impact Profile) & $\begin{array}{c}n \\
(\%)\end{array}$ & Very often & Fairly often & Occasionally & Hardly ever & Never \\
\hline \multirow{4}{*}{$\begin{array}{l}\text { Functional } \\
\text { limitation }\end{array}$} & \multirow{2}{*}{$\begin{array}{l}\text { 1. Have you had trouble pronouncing any words because } \\
\text { of problems with your teeth, mouth or dentures? }\end{array}$} & $n$ & 2 & 2 & 5 & 8 & 25 \\
\hline & & $\%$ & 4.80 & 4.80 & 11.90 & 19.00 & 59.50 \\
\hline & \multirow{2}{*}{$\begin{array}{l}\text { 2. Have you felt that your sense of taste has worsened because } \\
\text { of problems with your teeth, mouth or dentures? }\end{array}$} & $\mathrm{n}$ & 2 & 3 & 1 & 10 & 26 \\
\hline & & $\%$ & 4.80 & 7.10 & 2.40 & 23.80 & 61.90 \\
\hline \multirow{4}{*}{$\begin{array}{l}\text { Physical } \\
\text { pain }\end{array}$} & \multirow{2}{*}{ 3. Have you had painful aching in your mouth? } & $n$ & 4 & 3 & 7 & 10 & 18 \\
\hline & & $\%$ & 9.50 & 7.10 & 16.70 & 23.80 & 42.90 \\
\hline & \multirow{2}{*}{$\begin{array}{l}\text { 4. Have you found it uncomfortable to eat any foods because } \\
\text { of problems with your teeth, mouth or dentures? }\end{array}$} & $n$ & 3 & 5 & 6 & 15 & 13 \\
\hline & & $\%$ & 7.10 & 11.90 & 14.30 & 35.70 & 31.00 \\
\hline \multirow{4}{*}{$\begin{array}{l}\text { Psychological } \\
\text { discomfort }\end{array}$} & \multirow{2}{*}{$\begin{array}{l}\text { 5. Have you been aware of problems with your teeth, } \\
\text { mouth or dentures? }\end{array}$} & $n$ & 6 & 4 & 6 & 10 & 16 \\
\hline & & $\%$ & 14.30 & 9.50 & 14.30 & 23.80 & 38.10 \\
\hline & \multirow{2}{*}{$\begin{array}{l}\text { 6. Have you felt tense because of problems with your teeth, } \\
\text { mouth or dentures? }\end{array}$} & $n$ & 2 & 5 & 7 & 12 & 16 \\
\hline & & $\%$ & 4.80 & 11.90 & 16.70 & 28.60 & 38.10 \\
\hline \multirow{4}{*}{$\begin{array}{l}\text { Physical } \\
\text { disability }\end{array}$} & \multirow{2}{*}{$\begin{array}{l}\text { 7. Has your diet been unsatisfactory because of problems } \\
\text { with your teeth, mouth or dentures? }\end{array}$} & $n$ & 2 & 4 & 2 & 14 & 20 \\
\hline & & $\%$ & 4.80 & 9.50 & 4.80 & 33.30 & 47.60 \\
\hline & \multirow{2}{*}{$\begin{array}{l}\text { 8. Have you had to interrupt meals because of problems } \\
\text { with your teeth, mouth or dentures? }\end{array}$} & $n$ & 2 & 2 & 6 & 6 & 26 \\
\hline & & $\%$ & 4.80 & 4.80 & 14.30 & 14.30 & 61.90 \\
\hline \multirow{4}{*}{$\begin{array}{l}\text { Psychological } \\
\text { disability }\end{array}$} & \multirow{2}{*}{$\begin{array}{l}\text { 9. Have you found it difficult to relax because of problems } \\
\text { with your teeth, mouth or dentures? }\end{array}$} & $n$ & 2 & 3 & 3 & 14 & 20 \\
\hline & & $\%$ & 4.80 & 7.10 & 7.10 & 33.30 & 47.60 \\
\hline & \multirow{2}{*}{$\begin{array}{l}\text { 10. Have you been a bit embarrassed because of problems } \\
\text { with your teeth, mouth or dentures? }\end{array}$} & $\mathrm{n}$ & 3 & 3 & 6 & 13 & 17 \\
\hline & & $\%$ & 7.10 & 7.10 & 14.30 & 31.00 & 40.50 \\
\hline \multirow{4}{*}{$\begin{array}{l}\text { Social } \\
\text { disability }\end{array}$} & \multirow{2}{*}{$\begin{array}{l}\text { 11. Have you been a bit irritable with other people because } \\
\text { of problems with your teeth, mouth or dentures? }\end{array}$} & $n$ & 3 & 1 & 3 & 11 & 24 \\
\hline & & $\%$ & 7.10 & 2.40 & 7.10 & 26.20 & 57.10 \\
\hline & \multirow{2}{*}{$\begin{array}{l}\text { 12. Have you had difficulty doing your usual jobs because } \\
\text { of problems with your teeth, mouth or dentures? }\end{array}$} & $n$ & 2 & 2 & 4 & 6 & 28 \\
\hline & & $\%$ & 4.80 & 4.80 & 9.50 & 14.30 & 66.70 \\
\hline \multirow{4}{*}{ Handicap } & \multirow{2}{*}{$\begin{array}{l}\text { 13. Have you felt that life in general was less satisfying because } \\
\text { of problems with your teeth, mouth or dentures? }\end{array}$} & $\mathrm{n}$ & 3 & 3 & 6 & 9 & 21 \\
\hline & & $\%$ & 7.10 & 7.10 & 14.30 & 21.40 & 50.00 \\
\hline & \multirow{2}{*}{$\begin{array}{l}\text { 14. Have you been totally unable to function because } \\
\text { of problems with your teeth, mouth or dentures? }\end{array}$} & $n$ & 2 & 0 & 5 & 10 & 25 \\
\hline & & $\%$ & 4.80 & 0.00 & 11.90 & 2.80 & 59.50 \\
\hline
\end{tabular}

Table 3. Comparison of the well-being of patients after injury of the lower face, after 2 days and 8 month later

\begin{tabular}{|l|c|c|c|c|}
$\begin{array}{c}\text { Descriptive } \\
\text { statistics } \\
\text { [points] }\end{array}$ & $\begin{array}{c}\text { 2 days after } \\
\text { surgery }\end{array}$ & $\begin{array}{c}8 \text { months } \\
\text { after } \\
\text { surgery }\end{array}$ & Difference & $\begin{array}{c}\text { Wilcoxon } \\
\text { test }\end{array}$ \\
\hline Mean \pm SD & $25.1 \pm 15.5$ & $13.2 \pm 13.8$ & $11.9 \pm 11.7$ & $\mathrm{~N}=39$ \\
Median & 24.5 & 9.5 & 10.5 & $\mathrm{Z}=4.87$ \\
Minimum & 0.0 & 0.0 & -13.0 & $\mathrm{p}=0.0000^{* * *}$ \\
Maximum & 56.0 & 56.0 & 32.0 & \\
\hline
\end{tabular}

Fig. 1 illustrates the scores acquired by the respondents 2 days after the trauma, and 8 months later. It shows that the curve for the values 2 days after the trauma is located in the proximity of higher values on the " $x$ " axis, and the results recorded 8 months after the trauma create a curve whose peak corresponds to lower values on the " $\mathrm{x}$ " axis. The distribution of the results confirms the statistically significant improvement in the patients' well-being after a longer period of time from the injury, as evidenced by the Wilcoxon test.

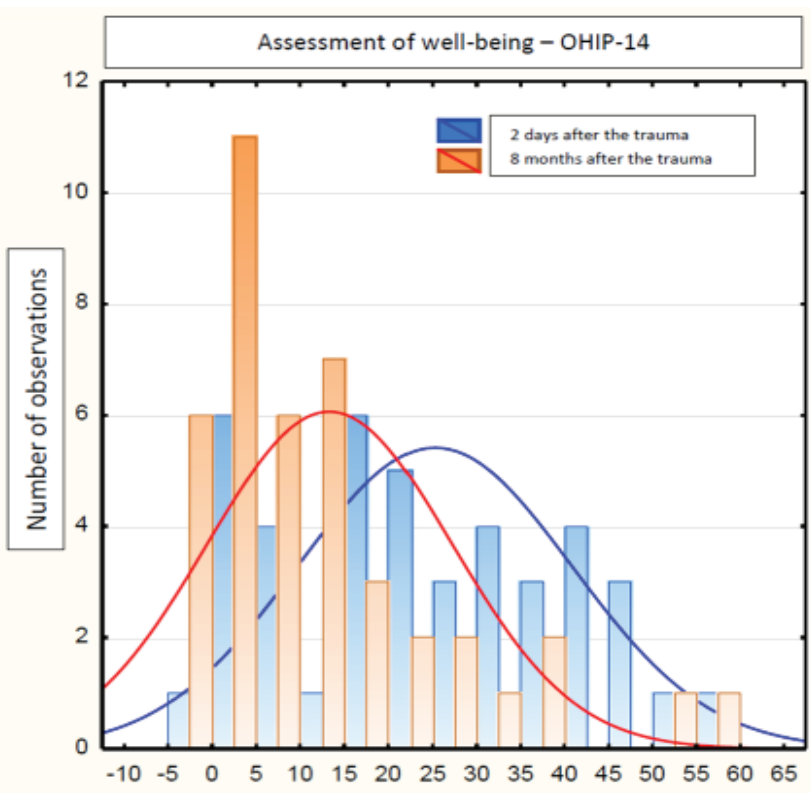

Fig. 1. Comparative assessment of patients' well-being, as measured with Oral Health Impact Profile (OHIP-14) 


\section{Improvement in patients' well-being after injury of the lower face, depending on age and sex}

Statistical analysis with the Spearman's rank correlation test has confirmed that there was no effect of age $(p=0.2839)$ or sex ( $p=0.6047)$ of subjects in the level of improvement in their well-being after the trauma. The relationships were statistically insignificant, at $\mathrm{p}<0.05$, both for the factor of age in the Spearman's rank correlation test and for sex in the Mann-Whitney $U$ test. The absolute values were in the range from $|R=0.0|$ to $|R=0.2|$, which shows no correlations with these factors. The data is shown in Table 4.

\section{Discussion}

Although they are characterized by significant strength and resistance to stress, skeletal structures of the facial part of the cranium, because of their location, are at high risk of traumatic injuries. Craniofacial injuries with bone fractures lead to various health-related consequences, including functional impairment of the local muscles and soft tissues. In view of the fact that normal functioning of the motor structures linked with the stomatognathic system is indispensable for such vital processes as breathing, articulation, mastication and swallowing of food, as well as sense of taste, any related dysfunctions may lead to significant discomfort experienced by patients, especially during the short post-trauma period. ${ }^{14,15}$

The present study was an attempt to identify the most common complaints connected with the physical and psychological well-being of patients following trauma located in the lower regions of the facial part of the cranium. From the clinical point of view, it seemed interesting to find out whether, and if so, what kind of, changes could be observed in patients' quality of life after traumatic injury; because of this, the assessment was performed 2 days and 8 months after the trauma. The results explicitly show significant improvement in the quality of life during that period, in comparison to the initial condition at the short post-trauma stage.

An assessment with the same research tool was carried out by Conforte et al. in a group of patients with craniofacial injuries, immediately after trauma, and then 30 and 60 days later. ${ }^{16}$ The present findings corroborate those reported by Conforte et al., who also observed time-related improvements in the quality of life after mandibular fractures.
Similarly, Kaukola et al. have reported significantly lower quality of life in patients with mandibular fractures in the short post-operative period in comparison to healthy controls. ${ }^{17}$ Conforte et al. observed improvement in daily functioning within the period of 3 months after trauma, and they suggested that this length of time was sufficient for the patients to achieve a quality of life similar to that in the control group. The authors also reported that sensory impairments were the most burdensome consequence of the trauma. ${ }^{17}$

The present study shows slightly different findings. Analysis of the most common complaints in the short postoperative period shows that most patients reported strong pain in the injured area. The most commonly indicated problem was the functional impairment related to eating selected foods. A significant number of the subjects emphasized difficulties connected with eating and dissatisfaction resulting from adopting a liquid diet. Similar functional problems were pointed out by Omeje et al., who showed that in a group of subjects with mandibular fractures, during the short post-trauma period, the most significant complaints included problems with chewing and swallowing as well as limitations in the options of food to eat. ${ }^{18}$

In the literature, there are many publications discussing the effects of injuries to the mental state and the related risk of depression. ${ }^{19}$ According to Rustemeyer and Gregersen, the most significant post-traumatic changes are connected with psychological discomfort and poorer social functioning. ${ }^{20}$ The neuropsychological consequences of craniofacial injuries were also pointed out, e.g. by Snell et al., who reported a one-year follow-up observation of patients with severe injury to the craniofacial skeleton due to road accidents. They found that in $30 \%$ of the subjects, injuries to the facial skeleton may significantly impair the emotional sphere, and lead to personality changes and to poorer social performance. The authors also emphasized that a decrease in the quality of life could be observed not only in the victims but also in their close family. ${ }^{21}$

Notably, our study shows evidence that even after 8 months from the injury, the majority of the patients present an unsatisfactory mental condition, which suggests it is necessary to introduce early psychological support for these patients. The present study has not confirmed that gender affects improvement in the patient's well-being. Similar opinions were expressed by Rustemeyer and Gregersen, as well as Barros et al., who did not find significant differences in the assessment of the quality of life of female and male subjects following craniofacial surgery. ${ }^{21,22}$

Table 4. Improvement in patients' well-being after injury of the lower face relative to sex and age

\begin{tabular}{|c|c|c|c|c|}
\hline Level of improvement & \multirow{2}{*}{\multicolumn{2}{|c|}{ Age }} & Spearman's R & p-value \\
\hline Assessment of well-being - OHIP-14 & & & -0.2 & 0.2839 \\
\hline \multirow{2}{*}{ Level of improvement } & \multicolumn{2}{|c|}{ Sex } & \multicolumn{2}{|c|}{ Mann-Whitney $U$ test } \\
\hline & females & males & Z & p-value \\
\hline Assessment of well-being - OHIP-14 & $14.2 \pm 13.2$ & $10.9 \pm 11.0$ & -0.52 & 0.6047 \\
\hline
\end{tabular}


Despite the observable improvement in oral-health related quality of life (OHIP-14), another important problem that should be investigated is the effect of duration of convalescence on the quality of life following craniofacial injury. Borgiel-Marek et al., basing on a study involving 89 patients with mandibular condyle fracture, have shown that favorable effects of treatment and recovery largely depend on the timing of rehabilitation, and only to a lesser degree on the method of surgical treatment. ${ }^{23}$

In the present study the authors have focused on assessing the quality of life resulting from complaints and general and psychological well-being of patients following injury of the lower face. It would seem justified to expand the assessment of the quality of life, especially following massive craniofacial injuries associated with multiple injuries, by examining the effects of specific treatment methods, and physical as well as manual therapy applied to the stomatognathic system, which may constitute a significant element of the multidisciplinary treatment process. $^{24,25}$ Complex collaboration between maxillofacial surgeons and physiotherapists may reduce the duration of convalescence and recovery. ${ }^{26,27}$

\section{Conclusions}

During both the short- and long-term period following injury of the lower face, the most frequent complaints included pain in the maxillofacial region, problems with eating food and dissatisfaction due to change in diet. The study has shown that, during the period of 8 months after the injury, there was a significant improvement in the quality of life assessed with OHIP-14. Age and gender do not significantly affect the quality of life after injury to the lower face.

\section{References}

1. Choi SH, Gu JH, Kang DH. Analysis of traffic accident-related facial trauma. J Craniofac Surg. 2016;27:1682-1685.

2. Einy S, Abdel Rahman N, Siman-Tov M, Aizenbud D, Peleg K. Maxillofacial trauma following road accidents and falls. J Craniofac Surg. 2016;27:857-861.

3. Subhashraj K, Nandakumar N, Ravindran C. Review of maxillofacial injuries in Chennai, India: A study of 2748 cases. Br J Oral Maxillofac Surg. 2007;45:637-639.

4. Singaram M, G SV, Udhayakumar RK. Prevalence, pattern, etiology, and management of maxillofacial trauma in a developing country: A retrospective study. J Korean Assoc Oral Maxillofac Surg. 2016;42:174-181.

5. Siber S, Matijevic M, Sikora M, Leovic D, Mumlek I, Macan D. Assessment of oro-maxillofacial trauma according to gender, age, cause and type of the injury. Acta Stomatol Croat. 2015;49:340-347.

6. Manodh P, Prabhu Shankar D, Pradeep D, Santhosh R, Murugan A. Incidence and patterns of maxillofacial trauma - a retrospective analysis of 3611 patients - an update. Oral Maxillofac Surg. 2016;20:377-383.

7. Jeon EG, Jung DY, Lee JS, et al. Maxillofacial trauma trends at a tertiary care hospital: A retrospective study. Maxillofac Plast Reconstr Surg. 2014;36:253-258.

8. Deliverska EG. Maxillofacial fractures in patients with multiple injuries and polytrauma. JIMAB, 2016;22:1120-1126.
9. Singh V, Malkunje L, Mohammad S, Singh N, Dhasmana S, Das SK. The maxillofacial injuries: A study. Natl J Maxillofac Surg. 2012;3:166-171.

10. Ziołecka B. Health related quality of life in rehabilitation of masticatory complex. Dent Forum. 2011;29(2):69-72 [in Polish].

11. Shiraz F, Rahtz E, Bhui K, Hutchison I, Korszun A. Quality of life, psychological well-being and treatment needs of trauma and head and neck cancer patients. Br J Oral Maxillofac Surg. 2014;52:513-517.

12. Slade GD, Spencer AJ. Development and evaluation of the oral health impact profile. Community Dent Health. 1994;11:3-11.

13. Alzarea BK. Assessment and evaluation of quality of life (OHRQoL) of patients with dental implants using the oral health impact profile (OHIP-14) - a clinical study. J Clin Diagn Res. 2016;10:57-60.

14. Holbrook TL, Hoyt DB. The impact of major trauma: Quality-of-life outcomes are worse in women than in men, independent of mechanism and injury severity. J Trauma. 2004;56:284-290.

15. Lento J, Glynn S, Shetty V, Asarnow J, Wang J, Belin TR. Psychologic functioning and needs of indigent patients with facial injury: A prospective controlled study. J Oral Maxillofac Surg. 2004;62:925-932.

16. Conforte JJ, Alves CP, Sánchez Mdel P, Ponzoni D. Impact of trauma and surgical treatment on the quality of life of patients with facial fractures. Int J Oral Maxillofac Surg. 2016;45:575-581.

17. Kaukola L, Snäll J, Lindqvist C, et al. Health-related quality of life after surgical treatment of mandibular fracture. Oral Surg Oral Med Oral Pathol Oral Radiol. 2015;119:402-407.

18. Omeje KU, Adebola AR, Efunkoya AA, et al. Prospective study of the quality of life after treatment of mandibular fractures. Br J Oral Maxillofac Surg. 2015;53:342-346.

19. Prashanth NT, Raghuveer HP, Kumar D, Shobha ES, Rangan V, Rao TSS. Anxiety and depression in facial injuries: A comparative study. J Int Oral Health. 2015;7:94-100.

20. Rustemeyer J, Gregersen J. Quality of life in orthognathic surgery patients: Post-surgical improvements in aesthetics and self-confidence. J Craniomaxillofac Surg. 2012;40:400-404.

21. Snell BJ, Roberts RM, Anderson P, David DJ. Neuropsychologic outcomes in patients treated for complex maxillofacial trauma. J Craniofac Surg. 2014;25:1164-1167.

22. Barros Vde M, Seraidarian PI, Cortes MI, de Paula LV. The impact of orofacial pain on the quality of life of patients with temporomandibular disorder. J Orofac Pain, 2009;23:28-37.

23. Borgiel-Marek H, Drugacz J, Marek B, Jędrusik-Pawłowska M, Głogowska-Szeląg J Witalińska-Łabuzek J. Long-term outcome in the treatment of mandibular condylar fractures. Ortop Traumatol Rehabil. 2005;7:425-432 [in Polish].

24. Wieckiewicz M, Boening K, Wiland P, Shiau YY, Paradowska-Stolarz A. Reported concepts for the treatment modalities and pain management of temporomandibular disorders. J Headache Pain, 2015;16:106.

25. Wojtyńska E, Bączkowski B, Przybyłowska D, Cierech M, Mierzwińska-Nastalska E, Zadurska M. A multidisciplinary treatment of patients with craniofacial disorders. Own experience. Dev Period Med. 2015;19:464-470.

26. Rashid A, Matthews NS, Cowgill H. Physiotherapy in the management of disorders of the temporomandibular joint; perceived effectiveness and access to services: A national United Kingdom survey. Br J Oral Maxillofac Surg. 2013;51:52-57.

27. Olivos V, Luongo P, Sarzosa M. Physiotherapy management postsurgery reconstructive maxillofacial region. Int J Oral Maxillofac Surg. 2011;40:1125-1135. 